\title{
Local honey goat milk yoghurt production. Process and quality control
}

\author{
Nesrine FEKNOUS ${ }^{1 \star}$ (D), Lina Lamis OUCHENE ${ }^{1}$, Mahieddine BOUMENDJEL ${ }^{2}$, Djamel-Eddine MEKHANCHA ${ }^{3}$, \\ Yasmine BOUDIDA ${ }^{3}$, Ahmed CHETTOUM ${ }^{4}$, Amel BOUMENDJEL ${ }^{2}$, Mahfoud MESSARAH ${ }^{2}$
}

\begin{abstract}
The aim of the present work is to set up a production process of goat milk-based yoghurt. Six (06) kinds of yoghurt have been prepared: a mixed unflavored yoghurt with $50 \%$ cow \& goat milk, a mixed flavored yoghurt with $50 \%$ cow \& goat milk, an unflavored $100 \%$ goat-milk-based yoghurt, a flavored $100 \%$ goat-milk-based yoghurt, two types of $100 \%$ goat milk-based yoghurts supplemented with natural honey. Results of bacteriological analyses of finished products showed the total absence of pathogenic bacteria Staphylococcus aureus and salmonella as well as the indicator hygiene bacteria like the fecal and total coliforms. Sensory analyses revealed that $100 \%$ goat-milk-based yoghurts are always better appreciated in the other categories (flavored or unflavored) compared to 50\% mixed yoghurts. Sensory analyses reported that yoghurts made with honey (HGM1 and HGM2) were richer in carbohydrates $(10.5 \mathrm{~g})$ and in energy (89.1 kilocalories) against natural yoghurts and flavored yoghurts, which recorded a carbohydrate content of $5.3 \mathrm{~g}$ and 68.3 kilocalories. The protein contents were assessed at $3.9 \mathrm{~g}$. Levels of lipids were at $3.5 \mathrm{~g}$ together with amounts in minerals such like: calcium, phosphorous, potassium and sodium which reached respectively $168 \mathrm{mg}, 114 \mathrm{mg}, 203 \mathrm{mg}$ and $58 \mathrm{mg}$.
\end{abstract}

Keywords: goat milk; yoghurt; honey; physical chemistry; bacteriology; nutritional value; energy value.

Practical Application: Goat milk is referred to as a therapeutic food for malnourished children and various dairy products are derived from its transformation. That goat milk can be used as a substitute to cow milk in the production of probiotic food like yoghurts. Adding honey as a natural sweetener makes it possible to increase its nutritional, energy value, and sensory ranking. The findings of hedonic analysis in the present study disclose that goat milk can serve in the preparation of yoghurts as very highly enjoyed by consumers.

\section{Introduction}

Goat milk is regarded by Desjeux (1993) as a therapeutic food and became widely consumed in the word regarding to its nutritional and microbiological qualities (Feknous et al., 2018). Its specific lipid composition provides it with an interesting nutritional value (Araújo et al., 2021; Ceballos et al., 2009). Raynal-Ljutovac et al. (2008) stated that the size of fat globules and its fatty acids content in short and medium chain enable the absorption of fats and supply energy to malnourished children. A team of pediatricians has also highlighted that it was possible - thanks to this milk - to successfully refeeding children showing intolerance to bovine proteins (Roy, 2003). Desjeux (1904) noticed an increase in weight in sick children after consuming this milk which contains almost as much selenium as in human milk and twice as much glutathione peroxydase than cow milk (Lambert-Lagacé, 1999; Hadjimbei et al., 2019). Selenium is a required metal for the enzymatic activity of glutathione peroxydase involved in reducing the free radicals. An American study has established that selenium concentration of goat milk is close to that of the human milk and that the glutathione peroxydase activity is higher in goat milk (Debski et al., 1987). Moreover, this milk includes nearly twice as much Pro-Vitamin A under the form of retinol than cow milk (Lambert-Lagacé, 1999). This milk contains generally higher calcium, magnesium and copper content (Fangmeier et al., 2019; Lucatto et al., 2020) and more potassium and phosphorus than cow milk. It also has a high alkalinizing ability and buffering capacity, thereby contributing -inter alia- maintaining a good skeletal mass (Lambert-Lagacé, 1999). Several products are derived from the transformation of goat milk like cheese (Soustre, 2007; Boumendjel et al., 2017; Öztürk \& Akin, 2018; Shabbir et al., 2019; Tadjine et al., 2020; Frau et al., 2021), cream cheese (Fangmeier et al., 2019) yoghurt such as 'dulce de leche' (Chaves et al., 2018), sour milk, kefir, clarified butter prepared in India and Iran along with infant formulae made in Taiwan, New Zealand and Australia. In Greece, goat milk-based yoghurts are sold in local markets (Kalantzopoulos, 1993). Yoghurt is a diary product that is popular to consumers which makes it an easy choice as a carrier of probiotic strains (Farnworth, 2008; Ranadheera et al., 2019). According to Kalliomäki et al. (2001) ; Mercenier et al. (2003) and Gourbeyre et al. (2011): Probiotics consumption allows: improved lactose digestion, increase nutritional value, regulating intestinal motility, preventing osteoporosis, cancer,

Received 10 May, 2021

Accepted 21 Jun., 2021

${ }^{1}$ Research Laboratory on Biodiversity and Ecosystems Pollution, Faculty of Nature and Life Sciences, Chadli Bendjedid University of El-Tarf, El Tarf, Algeria

${ }^{2}$ Research Laboratory on Biochemistry and Environmental Toxicology, Faculty of Sciences, Badji Mokhtar University of Annaba, Annaba, Algeria

${ }^{3}$ Institut de la Nutrition, de l'Alimentation et des Technologies Agro-Alimentaires - INATAA, Laboratoire de recherche Alimentation, Nutrition et Santé - ALNUTS, Université

Frères Mentouri Constantine 1, Constantine, Algeria

${ }^{4}$ Direction Régionale du Commerce, Annaba, Algeria

*Corresponding author: nesrinefeknous23@gmail.com 
hypertension and atherosclerosis, reducing cholesterol VLDL levels and immune system modulation in addition to decreasing inflammation or allergic reactions (Mituniewicz-Małek et al., 2019). In an effort to make sick children better accept goat milk due to its particular and stronger taste relative to other milks, we focused in the present study on setting up a manufacturing process of a goat-milk based yoghurt accompanied with a natural flavoring product, honey. To do so, six (06) types of yoghurt were prepared : an unflavored mixed cow and goat milk at $50 \%$, a flavored mixed cow and goat-milk at 50\%, an unflavored $100 \%$ goat-milk yoghurt, a flavored $100 \%$ goat-milk yoghurt, a flavored $100 \%$ goat-milk yoghurt, two types of $100 \%$ goat-milk yoghurts supplemented with natural honey. Physical chemical, microbiological, sensory and nutritional analyses were carried out on the prepared samples.

\section{Material and methods}

\subsection{Goat-milk sampling}

The goat-milk used in this study comes from a goat farm of alpine breed located at the mountainous region of Seraidi (city of Annaba, north east of Algeria). The breeding area of the goat herd is located at the north western side of the village of Seraidi (Figure 1), over the hills of Edough at all but $800 \mathrm{~m}$ altitude. The livestock is followed up by a veterinary doctor and is free of all pathologies or mastitis that could affect the bacteriological quality of collected milk.

\subsection{Vegetation Inventorying of the rangelands}

Inventorying of the existing plants at the region of Seraidi enabled to draw up the grazing itinerary and route of the goats. To do so, plant identification was done based on the herbarium of de Bélair (2019).

\subsection{Yoghurt production process}

Preparing yoghurts required in the first place a double pasteurization at two different temperatures: a first pasteurization of raw milk at $45^{\circ} \mathrm{C}$ during five minutes, then after adding $12.5 \mathrm{~g}$ of sugar, a second pasteurization at $95^{\circ} \mathrm{C}$ during 05 minutes. Sowing ferments (Streptococcus thermophilus and Lactobacillus delbureckii subsp bulgaricus YC-X16-CHR HANSEN) in an amount of $0.005 \mathrm{~g}$ in $125 \mathrm{ml}$ of cooled milk at $45^{\circ} \mathrm{C}$ is achieved, followed by adding $0.125 \mathrm{~mL}$ of flavorant to produce flavored yoghurts. Honey yoghurts are developed in the same way by adding $15 \mathrm{~g}$ of honey in $125 \mathrm{~mL}$ of cooled milk at $45^{\circ} \mathrm{C}$. Parboiling of pots so prepared is done at $45^{\circ} \mathrm{C}$ during 5 to 6 hours. After fermentation, the yoghurts are stored in the refrigerator (between 4 to $6^{\circ} \mathrm{C}$ ) prior to analysis.

\subsection{Physical-chemical analysis}

Physical chemical analyses were performed on the raw material (goat milk) as well as yoghurts. The following parameters were undertaken: $\mathrm{pH}$, acidity, total dry extract, fat content. Acidity is titrated against $\mathrm{NaOH}(0.01 \mathrm{~N})$ on a $10 \mathrm{~mL}$ sample while adding 2 to 3 drops of phenolphthalein. Milk density is measured by way of Gerber lactometer. Fat content is calculated by introducing in a butyrometer $10 \mathrm{ml}$ of sulfuric acid $(91 \%), 11 \mathrm{~mL}$ of sample to be analyzed and $01 \mathrm{~mL}$ of Isoamyl alcohol. After shaking the butyrometer, the samples are centrifuged at $500 \mathrm{rpm}$ during $05 \mathrm{~min}$ at $65^{\circ} \mathrm{C}$. The results are reported in $\mathrm{g} / \mathrm{L}$ by direct reading on the butyrometer' scale. The total dry extract is found out by a Radwag type desiccator, the results of which are expressed in percentage (\%).

\subsection{Microbiological analysis}

After completion of a range of dilutions, coliforms are sought by in-depth sowing on desoxycholate agar. Incubation

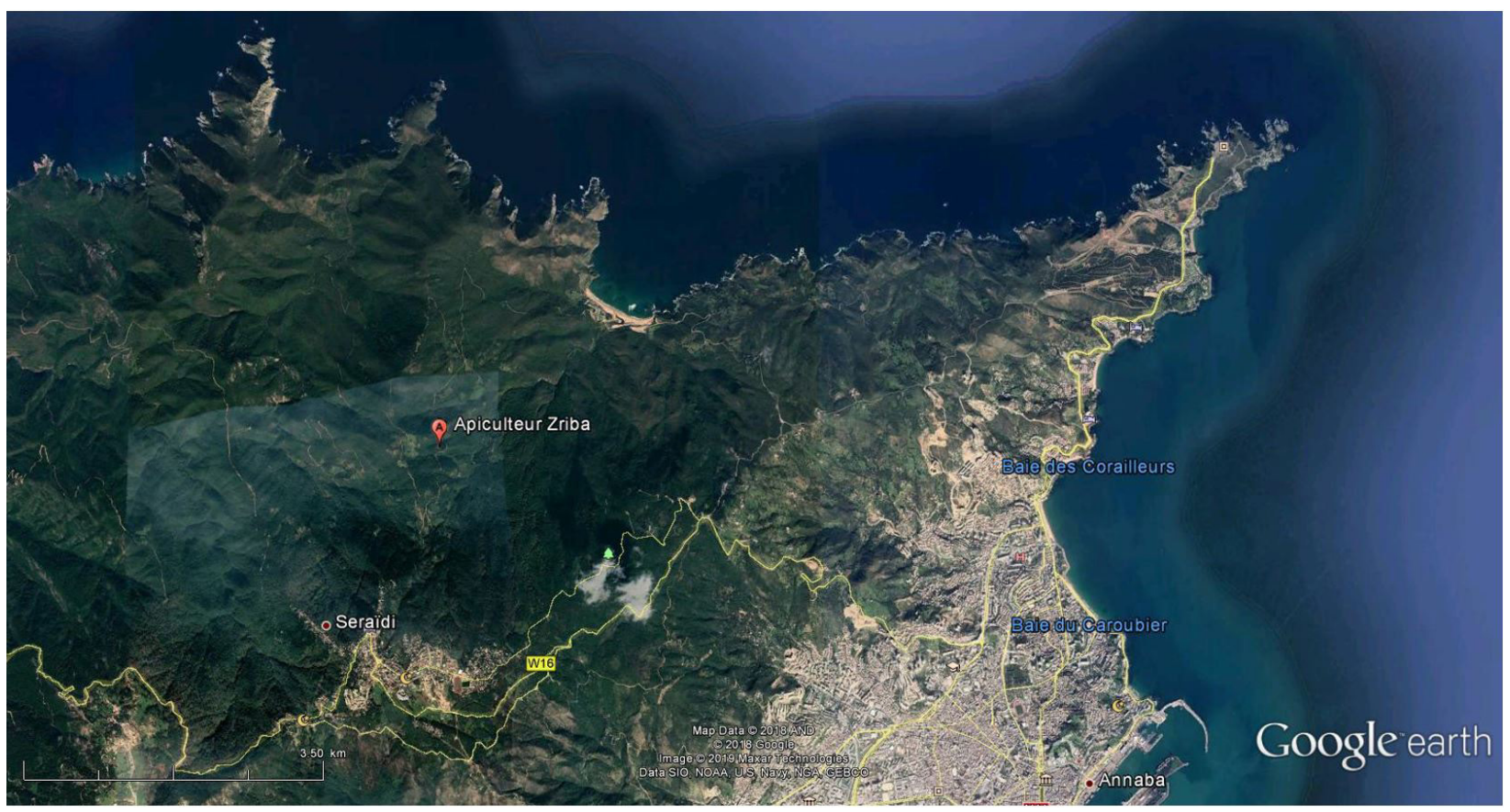

Figure 1. Localization map of apiculture and goat farm in Seraidi region. 
takes place during 24 hours for total coliforms and at $44-45^{\circ} \mathrm{C}$ during 48 hours for fecal coliforms. Tracking Staphylococus aureus required at first an enrichment in a Broth of Giolitti and Cantoni. The latter is incubated at $37^{\circ} \mathrm{C}$ during $24 \mathrm{~h}$. Isolation of Chapman medium is performed with incubation at $37^{\circ} \mathrm{C}$ during $24 \mathrm{~h}$ and identification by sowing the collected suspect colonies from the Chapman medium in a BHB broth. After incubation at $37^{\circ} \mathrm{C}$ over $24 \mathrm{~h}$, searching coagulase is achieved by sowing $0.5 \mathrm{~mL}$ of BHB and $0.5 \mathrm{~mL}$ of rabbit plasma. An observation of the plasma every two hours is conducted to monitor coagulation of the latter. As for salmonella, an enrichment of yoghurt samples is realized in a Selenite Cystine Broth (SCB) then incubated at $37^{\circ} \mathrm{C}$ for $24 \mathrm{~h}$. Isolation on a SS medium (Salmonella Schigella) is performed to ascertain the presence of pathogenic bacteria.

\subsection{Nutritional analysis}

The nutritional value along with the amount of macronutrients were reached for the sake of the following parameters: Energy value, proteins, carbohydrates, lipids and mineral salts (phosphorus, potassium, calcium and sodium), and this for $100 \%$ natural and honey goat milk-based yoghurts.

\subsection{Sensory analysis}

A hedonic analysis is carried out by an 'expert' panel of ten persons. This experienced panel is used to take part in all types of sensory tests of yoghurts at laboratory level. Sensory analyses covered six variants of prepared yoghurts: UGMY 50\%, FGMY 50\%, 100\% UGMY 100\%, FGMY 100\% and HGMY2 100\%. The taste panel is conducted in standard conditions and by filling out comment cards for the previously prepared goat milk yoghurts. The sensory analysis has therefore focused on the following visual, gustatory and olfactory parameters: General appearance, consistency, color, odor, general taste, acidity, sweetness and a final and overall assessment on the yoghurt. A Lickert scale is used to calculate the objectified average of collected feedbacks. The consistency and creaminess stand for key inputs for the consumer on the yoghurt quality (Schmidt et al., 1994).

\subsection{Benchmarking of yoghurts}

The results of the various physical-chemical and sensory analyses help ranking the yoghurts from 1 to 4 ( 1 being the best parameter score). An average grade of all scores is calculated for each of the examined yoghurts. A radar chart is drawn up in order to best view the comparison study altogether.

\subsection{Statistical analysis}

All of the obtained results are reported by the average of the repeated tests \pm standard deviation.

\section{Results and discussion}

\subsection{Vegetation inventorying of the rangelands}

After a series of field explorations, we have been able to identify the following list (Table 1) of plant species of Seraidi region that served to the pasture of goats from our livestock.
At least, 110 species are identified as being part of the livestock diet in Seraidi region. This large plant diversity would be behind the richness of the milk of this breed based in this region.

\subsection{Physical-chemical analysis of the raw material (goat milk)}

The results are reported in the following table (Table 2):

The $p H$

The $\mathrm{pH}$ of goat milk was at $6.70 \pm 0.007$ average value. As per Remeuf et al. (1989), the $\mathrm{pH}$ of goat milk reveals a slight acidity compared to cow milk, with an average of 6.7 .

\section{Acidity}

As per Vignola (2002), goat milk acidity ranges between 14 and $18^{\circ} \mathrm{D}$. The acidity of our sample is within the standards with a value of $17.377 \pm 0.506$ while the max value is $18^{\circ} \mathrm{D}$.

\section{Density}

According to Food and Agriculture Organization of the United Nations (1990), the density of goat milk varies between 1027 and 1035. The average density of our sample stands at $1028.555 \pm 2.364$ with a max value of 1029.4

\section{Total dry extract}

The total dry extract average of the goat milk sample used in our tests was at $13.73 \%$ while the max value is $14.45 \%$. The lactation stage has a big impact on the total solids content of goat milk (Mestawet et al., 2012). The peaks of these contents take place at the beginning (Mestawet et al., 2012) and towards the end of lactation (Haenlein, 2004). Our findings tally with those of Guo et al. (2001)who have found that the total dry extract of the goat milk mixture collected in the USA had the following values : $12.7 \%, 11.3 \%$ and $13.4 \%$.

\section{Fat content}

The butyric rate set forth by Pradal (2012) is between $33 \mathrm{~g} / \mathrm{kg}$ and $38 \mathrm{~g} / \mathrm{kg}$ against $36.15 \mathrm{~g} / \mathrm{kg}$ of the cow milk Grappin et al. (1981), our milk sample had a higher rate than the norm estimated at $40 \pm 7 \mathrm{~g} / \mathrm{kg}$ where the max value is $45 \mathrm{~g} / \mathrm{kg}$.

\section{Physical chemical analysis of the finished product (the yoghurt)}

The results of the physical chemical analysis of the yoghurts are outlined below:

\subsection{The pH}

The yoghurts prepared with $50 \%$ of goat milk experienced an average $\mathrm{pH}$ of $4.36 \pm 0.011$ for the UGMY and $4.36 \pm 0.005$ for the FGMY. The $100 \%$ goat milk yoghurts meanwhile averaged the following pH: $4.74 \pm 0.011$ for the UGMY, $4.75 \pm 0.011$ for the FGMY, $4.95 \pm 0.011$ for the HGMY1 and $4.91 \pm 0.011$ for the HGMY2 (Table 3). The results achieved indicate that the 
Table 1. Vegetation inventory of Seraidi region.

\begin{tabular}{|c|c|c|c|}
\hline Common name & French common name & Latin name & Arabic name \\
\hline Absinthe wormwood & Absinthe & Artemisia absinthium & مير مةشيشح \\
\hline Rosy garlic & Ail rose & Allium roseum & \\
\hline Three-cornered leek & Ail triquètre & Allium triquetrum & ابارلاموث \\
\hline Strawberry tree & Arbousier & Arbatus unedo & جنل \\
\hline Artichoke thistle & Artichaut sauvage & Cynara cardunculus & رملافشر خلا \\
\hline Wild asparagus & Asperge sauvage & Asparagus acutifolius & نويلهيرب \\
\hline Midland hawthorn & Aubépine & Crataegus laevigata & ير خجوب \\
\hline Common wild oat & Avoine, folle avoine & Avena fatua & لاطرخلا \\
\hline Azarole & Azérolier & Crataegus azarolus & رورعزل \\
\hline Basil & Basilic & Ocimum basilicum & قبحل \\
\hline Redstem filaree & Bec de Grue & Erodium cicutarium & معاسلا \\
\hline Borage & Bourache & Borago officinalis & شروبأ - فانشوب \\
\hline Quaking grass & Brize intermédiaire & Briza media & \\
\hline Big quaking grass & Grande brize & Briza maxima & \\
\hline Buglosse & Buglosse & Anchusa aggregata & مرقبلاناسل \\
\hline Garden anchusa & Buglosse azurée & Anchusa azurea & ن ن \\
\hline Spiny restharrow & Bugrane & Ononis spinosa & \\
\hline Thorny broom & Calycotome épineux & Calycotome spinosa & ل ل لودنقل \\
\hline Chamomile & Camomille romaine & Chamaemelum nobile & جنوبابل \\
\hline \multirow[t]{2}{*}{ Clustered bellflower } & Campanule agglomérée & Campanula glomerata & قسرج \\
\hline & Cardère sauvage & Dipsacus follonum & \\
\hline Wild carrot & Carotte sauvage & Daucus carota & مركسل \\
\hline Scallop-leaved mullein & Celsie sinuée & Verbascum sinuatum & \\
\hline Distaff thistle & Chardon à glue & Carlina gummifera & زككا \\
\hline Purple milk thistle & Chardon d'âne & Galactites tomentosa & عاضببلاةلكوشل \\
\hline \multirow[t]{2}{*}{ Cardus marianus } & Chardon Marie & Silybum marianum & كبل \\
\hline & Chèvrefeuille des Baléares & Lonicera implexa & \\
\hline Common chicory & Chicorée amère & Cichorium intybus & سيرس \\
\hline Couch grass & Chiendent officinal & Elytrigia repens & مجنل| - ودروبل| \\
\hline Garland chrysanthemum & Chrysanthème couronné & Chrysanthemum coronarium & (مزويلب \\
\hline Sage-leaved rock-rose & Ciste à feuilles de sauge & Cistus salviifolius & 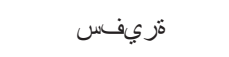 \\
\hline \multirow[t]{2}{*}{ Montpellier cistus } & Ciste de Montpellier & Cistus monspeliensis & 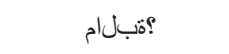 \\
\hline & Clématite à vrilles & Clematis cirrhosa & تطايخ \\
\hline Old man's beard & Clématite des haies & Clematis vitalba & 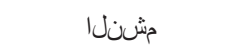 \\
\hline Cleonia & Cléone du Portugal & Cleonia lusitanica & \\
\hline Common poppy & Coqueliquot & Papaver rhoeas & شاخشخل \\
\hline Watercress & Cresson de fontaine & Nasturtium officinale & \\
\hline Cupidone & Cupidone & Catananche coerulea & قي ت \\
\hline Cynogloss & Cygnolosse de Crète & Cynoglossum creticum & 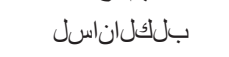 \\
\hline Mauritania grass & Diss ou ampelodes de Mauritanie & Ampelodesmos mauritanicus & سيدل| \\
\hline Southern globethistle & Echinops ou boule azurée & Echinops ritro & مركسل \\
\hline African valerian & Fédia ou corne d'abondance & Fedia cornucopiae & \\
\hline Fennel & Fenouil commun & Foeniculum vulgare & يربسابسب \\
\hline Common fumitory & Fumeterre & Fumaria officinalis & ن ن ن \\
\hline Common broom & Genêt à balai & Cytisus scoparius & \\
\hline Aulaga & Genêt épineux & Genista scorpius & ل ل لودنقل \\
\hline Dovesfoot geranium & Géranium à feuilles molles & Geranium molle & \\
\hline Wood cranesbill & Géranium des bois & Geranium sylvaticum & \\
\hline
\end{tabular}


Table 1. Continued...

\begin{tabular}{|c|c|c|c|}
\hline Common name & French common name & Latin name & Arabic name \\
\hline Sword lily & Glaïeul & Gladiolus communis & بارغلافيس \\
\hline Honeywort & Grand mélinet & Cerinthe major & ل لحنلاةرك \\
\hline Spotted rock-rose & Hélianthème à gouttes & Helianthemum guttatum & 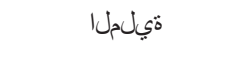 \\
\hline Heliotropium europaeum & Héliotrope d’Europe & Heliotropium europaeum & \\
\hline Red dead-nettle & Lamier pourpre & Lamium purpureum & \\
\hline Topped lavender & Lavande sauvage & Lavandula stoechas & 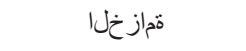 \\
\hline Narrowleaf flax & Lin annuel & Linum bienne & \\
\hline Field bindweed & Liseron des champs ou vrillée & Convolvulus arvensis & ق تجنـاقشيشح \\
\hline Mallow bindweed & Liseron fausse guimauve & Convolvulus althaeoides & \\
\hline Dwarf morning glory & Liseron tricolore ou belle du jour & Convolvulus tricolor & يربنسوس \\
\hline Birdsfoot deervetch & Lotier corniculé & Lotus corniculatus & ة \\
\hline Gypsywort & Lycope d'Europe & Lycopus europaeus & \\
\hline White horehound & Marrube blanc & Marrubium vulgare & 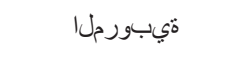 \\
\hline Common mallow & Mauve sauvage & Malva sylvestris & زيابخل \\
\hline Yellow sweet clover & Melilot officinal & Melilotus officinalis & \\
\hline Pennyroyal & Menthe pouliot & Mentha pulegium & 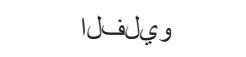 \\
\hline Hairy mint & Menthe velue & Mentha villosa & 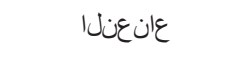 \\
\hline Scallop-leaved mullein & Molène & Verbascum sinuatum & 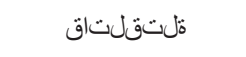 \\
\hline Blue pimpernel & Mouron bleu & Lysimachia foemina & \\
\hline Charlock mustard & Moutarde des champs ou Sanve & Sinapis arvensis & \\
\hline Blackberry & Mûrier ronce & Rubus fruticosus & قيلعل \\
\hline Common myrtle & Myrtes & Myrtus communis & شوملحل| - ناحيرل| \\
\hline European olive & Oliviers & Olea europea subsp europea & نوتيزل \\
\hline Roman nettle & Ortie à pilules ou ortie algérienne & Urtica pilulifera & مقير حلا \\
\hline African wood-sorrel & Oxalis & Oxalis pes-caprae & ةضيامحلا \\
\hline Common daisy & Pâquerette vivace & Bellis perennis & قن قايربلا - قمبازرلا \\
\hline
\end{tabular}

Table 2. Physical-chemical analysis of goat milk $(n=9)$.

\begin{tabular}{cccccc}
\hline Parameters & $\mathrm{pH}$ & Acidity & Density & Dry extract & Fat extract \\
\hline Results & $6.70 \pm 0.007$ & $17.37 \pm 0.506$ & $1028.55 \pm 2.364$ & $13.73 \pm 0.623$ & $40.00 \pm 7.00$ \\
\hline
\end{tabular}

Table 3. Physical chemical analysis of the six yoghurts $(n=3)$.

\begin{tabular}{ccccccc}
\hline & UGMY 50\% & FGMY 50\% & UGMY 100\% & FGMY 100\% & HGMY1 100\% & HGMY2 100\% \\
\hline pH & $4.36 \pm 0.111$ & $4.36 \pm 0.005$ & $4.74 \pm 0.011$ & $4.75 \pm 0.011$ & $4.95 \pm 0.011$ & $4.91 \pm 0.011$ \\
Acidity & $76.66 \pm 0.577$ & $77 \pm 0.00$ & $72 \pm 3.464$ & $71.88 \pm 3.271$ & $71 \pm 0.00$ & $70.33 \pm 0.577$ \\
Dry extract & $23.34 \pm 0.270$ & $23.24 \pm 0.308$ & $25.36 \pm 0.251$ & $25.34 \pm 0.219$ & $25.11 \pm 0.011$ & $25.1 \pm 4.351$ \\
Fat content & $39.33 \pm 6.350$ & $39.33 \pm 6.350$ & $29.36 \pm 2.281$ & $29.33 \pm 2.309$ & $32 \pm 0.00$ & $32 \pm 0.00$ \\
\hline
\end{tabular}

ferments used for preparing the yoghurts were viable and active and dropped the initial $\mathrm{pH}$ of goat milk that was at $6.70 \pm 0.007$. The two bacteria utilized in preparing the yoghurts Lactobacillus delbureckii subsp bulgaricus and Streptococcus thermophilus have the major role of reducing the milk's $\mathrm{pH}$ to the isoelectric point of casein ( $\mathrm{pH} 4,6$ ) so as to form a gel (Sodini \& Beal, 2012). With respect to goat milk, the isoelectric-pH is 4.2 (Moualek, 2011). Our pH findings are slightly higher than those concluded by Ghalem \& Zouaoui (2013), as well as to the $\mathrm{pH}$ of the fruits-enriched yoghurts of Caryocar brasiliense (Silva et al., 2014).

\subsection{Dornic acidity}

Acidity measurement of yoghurts UGMY50\%, FGMY50\%, UGMY100\%, FGMY100\%, HGMY1100\% and 
HGMY2 100\% respectively provided the following averages : $76.666 \pm 0.577^{\circ} \mathrm{D}, 77^{\circ} \mathrm{D}, 72 \pm 3.464^{\circ} \mathrm{D}, 71.888 \pm 3.271^{\circ} \mathrm{D}$, $71^{\circ} \mathrm{D}$ et $70.333 \pm 0.577^{\circ} \mathrm{D}$ (Table 3 ). These numbers are well above the acidity of the initial milk prior to fermentation $\left(17.377 \pm 0.506^{\circ} \mathrm{D}\right)$. According to Abdalla \& Ahmed (2010), this increased acidity relates to the growth of lactic bacteria which gradually convert lactose into lactic acid. Our results are lower than the acidity values found by Ghalem \& Zouaoui (2013) in parboiled natural and honey yoghurts enriched with officinal rosemary essential oils (Rosmarinus officinalis).

\subsection{Dry extract}

The dry extract of $50 \%$ goat milk yoghurts varies between $23.24 \pm 0.270 \%$ and $23.246 \pm 0.308 \%$ (Table 3 ). The Dry extract of natural and flavored $100 \%$ goat milk yoghurts ranges between $25.36 \pm 0.251 \%$ and $25.34 \pm 0.219 \%$. The dry extract of $100 \%$ goat milk supplemented with natural honey ranges from $25.113 \pm 0.011 \%$ to $25.11 \pm 4.351 \%$. The latter had high dry extracts because of the integration of honey to the yoghurts.

\subsection{Nutritional analyses}

The nutritional analyses showed that honey-prepared yoghurts HGM1 and HGM2 were richer in carbohydrates $(10.5 \mathrm{~g})$ and in energy (89.1 kilocalories) compared to natural and flavored yoghurts (NGMY and FGMY) which recorded a carbohydrate content of $5.3 \mathrm{~g}$ and 68.3 kilocalories. The refined sugar and artificial flavors are food additives that do not provide any nutritional value to food unlike honey which is a natural sweetener with a strong sweetening power and a distinctive taste. Honey is a high energy content food (Belhaj et al., 2015), natural, its specific composition might change according to its floral origin. Honey is a nutrient-rich food. Its structure is complex and contains at least 181 various substances (Alvarez-Suarez et al., 2010), the major compounds are the monosaccharides : glucose (around 30 to $40 \%$ of the dry matter) and some minor components like enzymes, amino acids, lipids, vitamins, phenolic acids, flavonoids and minerals (Manzanares et al., 2011), Honey has several nutritional and therapeutic properties (Peter, 2006). , Furthermore, it serves as a natural source of antioxidants, the latte play a major role in reducing the risks of heart disease, cancer, immune system and different inflammatory processes (Bertoncelj et al., 2007). The protein content of all yoghurts prepared with $100 \%$ goat milk: HGM1, HGM2, UGMY and FGMY were the same and measured at $3.9 \mathrm{~g}$. Ditto for the recorded lipid contents which were at $3.5 \mathrm{~g}$. The amounts of mineral salts like calcium, phosphorus, potassium, and sodium were respectively: $168 \mathrm{mg}$, $114 \mathrm{mg}, 203 \mathrm{mg}$ and $58 \mathrm{mg}$.

\section{Bacteriological analyses of the prepared yoghurts}

The results of the bacteriological tests are summed up in Table 4.

There is a total absence of total coliforms, fecal coliforms and pathogenic bacteria, like salmonella and the Staphylococcus aureus. This sterility is found in all of the studied parboiled natural and flavored yoghurts, making them products that are complying with the regulatory guidelines. (Algeria, 2017). Ghalem \& Zouaoui (2013) found the same conclusions in their works. The absence of bacteria stems from the fact that milk pasteurization was achieved at $95^{\circ} \mathrm{C}$, which helped destroy the pathogenic toxicogenic bacteria and other microorganisms whose growth might compete with that of the lactic ferments (Oteng-Gyang, 1984). On top of this, the protoccoperation generated from the combination of Streptococcus thermophilus with the Lactobacillus bulgaricus has made it possible to ensure the microbiological stability of the finished products. Yoghurt is fitted with an antibacterial effect on negative and positive Gram pathogenic bacteria like: Escherichia coli, Listeria monocytogenes and Salmonella sp. (Jasjit et al., 1979; Rubin \& Vaughan, 1979; Schaack \& Marth, 1988; Kotz et al., 1990). Lactic ferments of yoghurt are homofermentative, releasing lactic acid as a main product throughout carbohydrates fermentation (OtengGyang, 1984). The latter operates as an inhibitor towards undesirable microorganisms (Leory et al., 2002), because this organic acid plays the role of bactericidal. It provides an anti-microbial effect to the yoghurt (Wang et al., 2015), and that against Pseudomonas aeruginosa (at a concentration of $0.3 \%$ ), against Salmonella typhi (at 0.6\%), against Escherichia coli (at 2.25\%) and against Staphylococcus aureus at 7.5\% (Oteng-Gyang, 1984).

\section{Sensory analysis}

The results of the objectified sensory analyses are outlined in the following table. Each of the sensory parameters features a numerical rank going from 1 to 6 , starting from the best rank to the less good.

\subsection{Visual appearance}

Overall, it is clear from the sensory analysis that most yoghurts have a smooth aspect, or even average. According to Vignola (2002), parboiled or firm yoghurts are flavored or natural yoghurts, having a firm texture with a smooth surface. The two best obtained formulae are HGM1 and HGM2.

\subsection{Color}

Based on the achieved results, none of the yoghurts received a negative rating as to a very unpleasant color. Only $20 \%$ of the

Table 4. Bacteriological analyses of the prepared yoghurts.

\begin{tabular}{|c|c|c|c|c|c|c|c|}
\hline Bacteria & $\begin{array}{l}\text { NGM } \\
(50 \%)\end{array}$ & $\begin{array}{l}\text { FGM } \\
(50 \%)\end{array}$ & $\begin{array}{l}\text { NGM } \\
(100 \%)\end{array}$ & $\begin{array}{c}\text { FGM } \\
(100 \%)\end{array}$ & $\begin{array}{c}\text { HFGM1 } \\
(100 \%)\end{array}$ & $\begin{array}{c}\text { HFGM2 } \\
(100 \%)\end{array}$ & Standard ${ }^{*}$ \\
\hline Total coliforms & Abs & Abs & Abs & Abs & Abs & Abs & $10^{2}$ \\
\hline Fecal coliforms & Abs & Abs & Abs & Abs & Abs & Abs & $10^{2}$ \\
\hline Salmonella & Abs & Abs & Abs & Abs & Abs & Abs & Absence \\
\hline Staphylococcus aureus & Abs & Abs & Abs & Abs & Abs & Abs & $10^{2}$ \\
\hline
\end{tabular}

*Journal Officiel de la République Algérienne Démocratique et Populaire, n³9 (Algeria, 2017). 
tasters deemed that the $100 \%$ natural yoghurt was unpleasant against $30 \%$ who felt that the $100 \%$ natural yoghurt was pleasant and $50 \%$ fairly pleasant. This offers overall an approval result by the taste panel on yoghurts. The color of UGMY $50 \%$ was average for $60 \%$ and nice for $40 \%$ of the panel. FGM, HGM1 \& HGM2 yoghurts received a better rating by being ranked number one.

\subsection{Odor}

Goat milk is characterized by a particular flavor and a stronger taste than cow milk (Jooyandeh \& Abroumand, 2010). The fermentation of goat's milk with probiotic bacteria, can improving the sensory characteristics through decreasing the caprine smell (Vargas et al., 2008; Muelas et al., 2018). We were expecting that this odor would be pointed out by the taste panel, however, the majority of opinions weighed in favor of a good evaluation of the odor. Most opinions were divided (20 to 30\%) between the absence of odor and low odor for the four variants of honey-free yoghurt. Only $20 \%$ considered that the $100 \%$ flavored yoghurt had a very strong odor. Yet, this appraisal did not only relate to the goat origin of the milk but mainly the flavor added to the yoghurt because none of the tasters had knowledge of the animal origin of the used milk in the making of the yoghurts. Probiotics strains produce pleasant flavor compounds during fermentation (Balthazar et al., 2018). Only the honey yoghurts had a negative assessment as for lack of knowledge of the composition, the panel pointed out a strong odor on both HGM1 then HGM2 samples.

\subsection{Texture at tasting}

None of the textures of the four yoghurts is grainy. The majority of the panel stated that graininess in yoghurts was average to smooth. The consensus of the panel pertains to the smooth appearance of HGM1 with $100 \%$ positive responses going from smooth to very smooth. The texture of a food determines the approval or rejection of a food by the consumer (Budin, 2000). Some bacterial strains produce - from glucose- polysaccharides that by filament formation restrict gel alteration through mechanical processing and help in the viscosity of yoghurt (Schmidt et al., 1994). On top of its acidifying effect, Streptococcus thermophilus is responsible of the texture in sour milks. This bacteria enhances milk viscosity by producing polysaccharides, galactose compounds, glucose together with tiny amounts of rhamnose, arabinose and mannose (Bergamaier, 2002). An inconsistency might be caused by poor activity of the utilized ferments arising either from the degeneration of cultures or contamination of ferments through bacteriophages (Strahm et al., 2014). Hence, HGM1 then HGM2 yoghurts would have the highest likelihood of acceptance by the consumer.

\subsection{Acidity}

None of the tasters deemed the yoghurts were of very high acidity, which helps to products acceptance. Table 5 indicates that $50 \%$ goat $\&$ cow milk mixtures lead to a more acid taste evaluation of the yoghurts vis-à-vis $100 \%$ goat milk yoghurts which seem of low acidity. The best formula being that of HGM2.

\subsection{Sweetness}

Goat milk has a slightly sweet taste compared to cow milk. That would be expected to affect the assessment of 100\% goat milk yoghurts in comparison with $50 \%$ mixed yoghurts. However, the panel did not come up with a noticeable difference between $100 \%$ and $50 \%$ goat milk variants. This leads us to say that the amount of sugar added to the four variants have masked off the basic differences between 100\% goat milk and the 50\% mixture of cow and goat milk. Such an assessment is in favor of the use of goat milk whatever the percentage is as long as it was not actually detected during tasting. What is more, adding bitter honey helped it get ranked at the $05^{\text {th }}$ position, proving that this variant masks off very well the sweet taste of the yoghurt, as opposed to HGM2 which was ranked $02^{\text {nd }}$ in the same way as UGM $100 \%$ and UGM $50 \%$.

\subsection{Taste}

Goat milk is characterized by a particular flavor and a stronger taste than cow milk (Jooyandeh \& Abroumand, 2010). We noted in the results we had that of all the yoghurts, none had a negative evaluation regarding an extremely unpleasant taste and very unpleasant taste. Most found that the taste of the six variants was nice and very nice. The best assessment pertained to HGM2 yoghurt. Lactobacillus bulgaricus plays a primary role in the development of the yoghurt's organoleptic properties (Marty-Teysset et al., 2000). As a matter of fact, according to Tamime \& Robinson (1999) and Sudheer et al. (2006), the lactic acid produced during yoghurt making helps to disrupt casein

Table 5. Yoghourt ranking following sensory analysis.

\begin{tabular}{|c|c|c|c|c|c|c|}
\hline Parameters & NGM100 & FGM100 & NGM50 & FGM50 & HFGM1 & HFGM2 \\
\hline Visual appearance & 6 & 3 & 5 & 3 & 1 & 1 \\
\hline Color & 6 & 1 & 5 & 4 & 1 & 1 \\
\hline Odor & 3 & 4 & 1 & 1 & 6 & 5 \\
\hline Tasting & 2 & 4 & 6 & 2 & 5 & 1 \\
\hline Texture at tasting & 3 & 3 & 6 & 5 & 1 & 2 \\
\hline Acidity & 3 & 2 & 6 & 5 & 4 & 1 \\
\hline Sweetness & 2 & 1 & 2 & 5 & 2 & 5 \\
\hline Overall assessment & 2 & 1 & 6 & 2 & 2 & 2 \\
\hline Mean & 3.375 & 2.375 & 4.625 & 3.375 & 2.75 & 2.25 \\
\hline
\end{tabular}




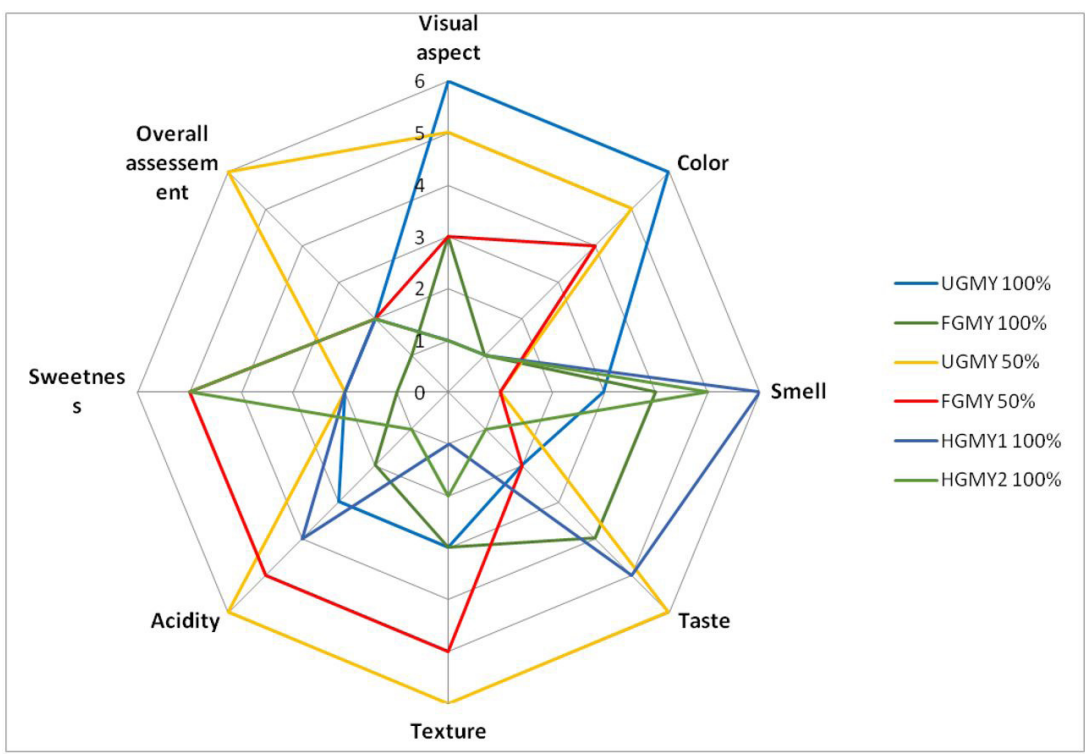

Figure 2. Quality and sensory radar chart of the six yoghurts.

micelles, leading to the formation of a gel giving the yoghurt a characteristic and distinct taste in contributing in the savor and flavoring (aromatization) of the yoghurt. This release of yoghurt's flavors masked off the initial imprints of the goat milk-based yoghurt leaving no indication of a great difference between the $100 \%$ variant and the $50 \%$ mixed variants.

\subsection{Overall assessment}

We reported from the sensory analysis that most yoghurts had a good overall review (appearance + color + odor + taste + texture + acidity + sweetness). Our yoghurts were given generally good to excellent rating with very little difference between the various variants.

\subsection{Comparative study and ranking of yoghurts}

Below is the radar chart (Figure 2) relating to the sensory parameters of the six tested yoghurts. The yoghurt having the lowest index (1) stands for the best organoleptic evaluation taken by the panel, and that for each of the eight tested parameters.

As per the chart below, HGM2 yoghurt ranks first with its overall score of 2.35, followed by FGM100 with a score of 2.375, followed by HGM1 with a score of 2.750 , then followed by the two variants UGM100 and FGM50 with 3.375 and ultimately comes at the last position UGM50 with a final score of 4.625 . We realize that $100 \%$ milks are always better appreciated in their category (flavored or not) in relation to $50 \%$ mixed milks. This very promising result leads to agree upon the fact of a good utilization of goat milks in yoghurt manufacturing. Besides, flavored yoghurts are better, chiefly honey's.

\section{Conclusion}

Results of physical-chemical analyses revealed that all of the yoghurts were within the standards. Microbiological analyses showed a total absence of pathogenic bacteria and hygiene quality indicator bacteria. The sensory analyses have also demonstrated that the flavored or unflavored $100 \%$ yoghurts were more appreciated than yoghurts made of $50 \%$ mixed milks. Nutritional analyses of whole-goat milk yoghurts (100\%) denoted that honey yoghurts (HGM1 \& HGM2) were richer in carbohydrates and in energy vis-à-vis 100\% natural and flavored yoghurts (UGMY \& FGMY). The sensory analysis allowed ranking the natural goat milk and flavored yoghurt number one out of the six variants. The findings of the present study disclose that goat milk can serve in the preparation of yoghurts as very highly enjoyed by consumers. Adding up another natural product like mountain honey improves its ranking relative to the other variants.

\section{Conflict of interest}

The authors declare that they have no conflict of interest.

\section{Acknowledgements}

The present work was supported by DGRSDT (General Directorate of Scientific Research and Technological Development, Algeria).

\section{References}

Abdalla, M. O. M., \& Ahmed, S. Z. A. N. (2010). Chemical composition of mish "A Traditional Fermented Dairy Product" from different plants during storage. Pakistan Journal of Nutrition, 9(3), 209-212. http://dx.doi.org/10.3923/pjn.2010.209.212.

Algeria. (2017). Arrêté interministériel du 4 octobre 2016 fixant les critères microbiologiques des denrées alimentaires. Journal Officiel de la République Algérienne Démocratique et Populaire. no. 39.

Alvarez-Suarez, J.M., Tulipani, S., Diaz, D., Estevez, Y., Romandini, S., Giampieri, F., Damiani, E., Astolfi, P., Bompadre, S., \& Battino, M. (2010). Antioxidant and antimicrobial capacity of several monofloral Cuban honeys and their correlation with color, polyphénols content and other chemical compounds. Food and Chemical Toxicology, 48, 2490-2499. 
Araújo, N. G., Silva, J. B., Moreira, R. T., \& Cardarelli, H. R. (2021). Effect of temperature and concentration of $\beta$ eta-galactosidase on the composition of reduced lactose pasteurized goat milk. Food Science Technology, 41(2), 432-438. http://dx.doi.org/10.1590/fst.05220.

Balthazar, C. F., Silva, H. L. A., Esmerino, E. A., Rocha, R. S., Moraes, J., Carmo, M. A. V., Azevedo, L., Camps, I., Abud, Y. K. D., Sant'Anna, C., Franco, R. M., Freitas, M. Q., Silva, M. C., Raices, R. S. L., Escher, G. B., Granato, D., Senaka Ranadheera, C., Nazarro, F., \& Cruz, A. G. (2018). The addition of inulin and Lactobacillus casei 01 in sheep milk ice cream. Food Chemistry, 246, 464-472. http://dx.doi. org/10.1016/j.foodchem.2017.12.002. PMid:29291874.

Bélair, G. (2019). Herbier GdB. Retrieved from https://gdebelair.com/

Belhaj, O., Oumato, J., \& Zrira, S. (2015). Etude physico-chimiques de quelques types de miels marocains. Institut Agronomique et Vétérinaire Hassan II, Rabat, Maroc, 3(3), 71-75.

Bergamaier, D. (2002). Production d'exopolysaccharides par fermentation avec des cellules immobilisées de Lactobacillus rhamnosus RW-959M dans un milieu à base de permeat de lactosérum (Thèse de doctorat). Université de Laval, Québec.

Bertoncelj, J., Dobersek, U., Jamnik, M., \& Golob, T. (2007). Evaluation of phenolic content: antioxidant activity and colour of Slovenian honeys. Food Chemistry, 105(2), 822-828. http://dx.doi.org/10.1016/j. foodchem.2007.01.060.

Boumendjel, M., Feknous, N., Mekideche, F., Dalichaouche, N., Feknous, I., Touafchia, L., Metlaoui, N., \& Zenki, R. (2017). Caractérisation $\mathrm{du}$ lait de chèvre produit dans la région du Nord-est Algérien. Essai de fabrication du fromage frais. Algerian Journal of Natural Products, 5(2), 492-506.

Budin, J. P. (2000). Présentation de l'évaluation sensorielle: valorisation des produits laitiers des ovins et des caprins en méditerranée. France: Ed. Ciheam.

Ceballos, L. S., Morales, E. R., Adarve, G. T., Castro, J. D., Martinez, L. P., \& Sampelayo, M. R. S. (2009). Composition of goat and cow milk produced under similar conditions and analyzed by identical methodology. Journal of Food Composition and Analysis, 22(4), 322-329. http://dx.doi.org/10.1016/j.jfca.2008.10.020.

Chaves, M. A., Souza, A. H. P., Colla, E., Bittenccourt, P. R. S., \& Matsushita, M. (2018). Influences of chia flour and the concentration of total solids on the characteristics of 'dulce de leche' from goat milk. Food Science and Technology, 38(Suppl. 1), 338-344. http:// dx.doi.org/10.1590/1678-457x.22017.

Debski, B., Picciano, M. F., \& Milner, J. A. (1987). Selenium content and distribution of human, cow and goat milk. The Journal of Nutrition, 117(6), 1091-1097. http://dx.doi.org/10.1093/jn/117.6.1091. PMid:3037047.

Desjeux, E. (1904). L'alimentation par le lait cru chez l'enfant à létat de santé et à l'état de maladie. Tours: Imprimerie Deslis Frères.

Desjeux, J. F. (1993). Valeur nutritionnelle du lait de chèvre. Le Lait, 73(5-6), 573-580.

Fangmeier, M., Kemerich, G. T., Machado, B. L., Maciel, M. J., \& Souza, C. F. V. (2019). Effects of cow, goat, and buffalo milk on the characteristics of cream cheese with whey retention. Food Science and Technology, 39(Suppl. 1), 122-128. http://dx.doi.org/10.1590/ fst.39317.

Farnworth, E. R. (2008). Kefir: from folklore to regulatory approval. Journal of Nutraceuticals. Functional \& Medical Foods., 1(4), 57-68.

Feknous, N., Boumendjel, M., Mekideche, F., Dalichaouche, N., Zaafour, M., Mekhancha, D., Touafchia, L., Feknous, I., \& Zenki, R. (2018). Exploration de la qualité microbiologique des laits de chèvre du Nord-est algérien. Revue Agriculture, 9(1), 071-080.
Food and Agriculture Organization of the United Nations - FAO. (1990). Le lait et les produits laitiers dans la nutrition humaine. Rome: FAO.

Frau, F., Carate, J. N. L., Salinas, F., \& Pece, N. (2021). Effect of vacuum packaging on artisanal goat cheeses during refrigerated storage. Food Science Technology, 41(2), 295-303. http://dx.doi.org/10.1590/fst.36719.

Ghalem, B. R., \& Zouaoui, B. (2013). Microbiological, physico-chemical and sensory quality aspects of yoghurt enriched with Rosmarinus officinalis oil. African Journal of Biotechnology, 12(2), 192-198. http:// dx.doi.org/10.5897/AJB12.1257.

Gourbeyre, P., Denery, S., \& Bodinier, M. (2011). Probiotics, prebiotics, and synbiotics: impact on the gut immune system and allergic reactions. Journal of Leukocyte Biology, 89(5), 685-695. http://dx.doi. org/10.1189/jlb.1109753. PMid:21233408.

Grappin, R., Jeunet, R., Pillet, R., \& Toquin, A. (1981). Etude des laits de chèvre. I Teneur du lait de chèvre en matière grasse, matière azotée et fractions azotées du lait. Le Lait, 61(603-604), 117-133. http://dx.doi.org/10.1051/lait:1981603-6047.

Guo, M.R., Dixon, P.H., Park, Y.W. Gilmore, J.A., \& Kindstedt, P.S. (2001). Seasonal changes in the chemical composition of commingled goat milk. Journal of Dairy Science, 84, 79-83.

Hadjimbei, E., Botsaris, G., Goulas, V., Alexandri, E., Gekas, V., \& Gerothanassis, I. P. (2019). Functional stability of goats' milk yoghurt supplemented with Pistacia atlantica resin extracts and Saccharomyces boulardii. International Journal of Dairy Technology, 73(1), 134-143. http://dx.doi.org/10.1111/1471-0307.12629.

Haenlein, G. F. W. (2004). Goat mik in human nutrition. Small Ruminant Research, 51(2), 155-163. http://dx.doi.org/10.1016/j. smallrumres.2003.08.010.

Jasjit, S., Adarsh, K., \& Harish, C. (1979). Antibacterial activity of yogurt starter in cow and buffalo milk. Journal of Food Protection, 42(8), 664-665.

Jooyandeh, H., \& Abroumand, A. (2010). Physico-chemical, nutritional, heat treatment effects and dairy product aspects of goat and sheep milks. World Applied Sciences Journal, 11(11), 1316-1322.

Kalantzopoulos, G. (1993). Etat de la recherche sur le lait de chèvre en Grèce. Le Lait, 73(5-6), 431-441. http://dx.doi.org/10.1051/ lait:19935-641.

Kalliomäki, M., Salminen, S., Arvilommi, H., Kero, P., Koskinen, P., \& Isolauri, E. (2001). Probiotics in primary prevention of atopic disease: a randomized placebo controlled trial. Lancet, 357(9262), 1076-1079. http://dx.doi.org/10.1016/S0140-6736(00)04259-8. PMid:11297958.

Kotz, C. M., Peterson, L. R., Moody, J. A., Savaiano, D. A., \& Levitt, M. D. (1990). In vitro antibacterial effect of yogurt on Escherichia coli. Digestive Diseases and Sciences, 35(5), 630-637.

Lambert-Lagacé, L. (1999). Le lait de chèvre un choix santé. Montréal: Les éditions de l'Homme. 105 p.

Leory, F., Degeest, B., \& De Vuyst, L. (2002). A novel area of predictive modeling: describing the functionally of beneficial micro-organisms in foods. International Journal of Food Microbiology, 73, 251-259.

Lucatto, J. N., Silva-Buzanello, R. A., Mendonça, S. N. T. G., Lazarotto, T. C., Sanchez, J. L., Bona, E., \& Drunkler, D. A. (2020). Performance of different microbial cultures in potentially probiotic and prebiotic yoghurts from cow and goat milks. International Journal of Dairy Technology, 73(1), 144-156. http://dx.doi.org/10.1111/1471-0307.12655.

Manzanares, A. B., García, Z. H., Galdón, B. R., Rodríguez, E. R., \& Romero, C. D. (2011). Differentiation of blossom and honeydew honeys using multivariate analysis on the physicochemical parameters and sugar composition. Food Chemistry, 126(2), 664-672. http:// dx.doi.org/10.1016/j.foodchem.2010.11.003. 
Marty-Teysset, C., Torre, F., \& Garel, J. (2000). Increased production of hydrogen peroxide by Lactobacillus delbrueckii subsp. bulgaricus upon aeration: involvement of an NADH oxidase in oxidative stress. Applied and Environmental Microbiology, 66(1), 262-267. http://dx.doi.org/10.1128/AEM.66.1.262-267.2000. PMid:10618234.

Mercenier, A., Pavan, S., \& Pot, B. (2003). Probiotics as biotherapeutic agents: present knowledge and future prospects. Current Pharmaceutical Design, 9(2), 175-191. http://dx.doi.org/10.2174/1381612033392224. PMid:12570667.

Mestawet, T. A., Girma, A., Adnoy, T., Devold, T. G., Narvhus, J. A., \& Vegarud, G. E. (2012). Milk production. Composition and variation at different lactation stages of four goat breeds in Ethiopia. Small Ruminant Research, 105(1-3), 176-181. http://dx.doi.org/10.1016/j. smallrumres.2011.11.014.

Mituniewicz-Małek, A., Zielinska, D., \& Ziarno, M. (2019). Probiotic monocultures in fermented goat milk beverages-sensory quality of final product. International Journal of Dairy Technology, 72, 01-08.

Moualek, I. (2011) Caractérisation du lait de chèvre collecté localement : Séparation chromatographique et contrôle électrophorétiques des protéines (Thèse de doctorat). Université mouloud Mammeri Tizi Ouzou, Algérie.

Muelas, R., Olives, A. M., Romero, G., Diaz, J. R., Sayas, M. E., \& Sendra, E. (2018). Evaluation of individual lactic acid bacteria for the fermentation of goat milk: quality parameters. LebensmittelWissenschaft + Technologie, 98, 506-514. http://dx.doi.org/10.1016/j. lwt.2018.09.005.

Öztürk, H. I., \& Akin, N. (2018). Comparison of some functionalities of water soluble peptides derived from Turkish cow and goat milk Tulum cheeses during ripening. Food Science and Technology, 38(4), 674-682. http://dx.doi.org/10.1590/1678-457x.11917.

Peter, D. P. (2006). Beekeeping. Versailles: Macmillan Education. 163 p.

Pradal, M. (2012). La transformation fromagère caprine fermière : bien fabriquer pour mieux valoriser ses fromages de chèvres. Paris: Lavoisier (Tec et Doc). 295 p.

Ranadheera, C. S., Evans, C. A., Baines, S. K., Balthazar, C. F., Cruz, A. G., Esmerino, E. A., Freitas, M. Q., Pimentel, T. C., Wittwer, A. E., Naumovski, N., Graça, J. S., Sant'Ana, A. S., Ajlouni, S., \& Vasiljevic, T. (2019). Probiotics in goat milk products: delivery capacity and ability to improve sensory attributes. Comprehensive Reviews in Food Science and Food Safety, 18(4), 867-882. http:// dx.doi.org/10.1111/1541-4337.12447. PMid:33337004.

Raynal-Ljutovac, K., Lagriffoul, G., Paccard, P., Guillet, I., \& Chilliard, Y. (2008). Composition of goat and sheep milk products: an update. Small Ruminant Research, 79(1), 57-72. http://dx.doi.org/10.1016/j. smallrumres.2008.07.009.

Remeuf, F., Lenoir, J., Duby, C., Letilly, M.-T., \& Normand, A. (1989). Etude des relations entre les caractéristiques physico-chimiques des laits de chèvre et leur aptitude à la coagulation par la présure. Le Lait, 69(6), 499-518. http://dx.doi.org/10.1051/lait:1989634.
Roy, S. (2003). Le lait de chèvre: intolérance au lactose. Service Vie Inc., 17, 3-6.

Rubin, H. E., \& Vaughan, F. (1979). Elucidation of the inhibitory factors of yogurt against Salmonella typhimurium. Journal of Dairy Science, 62(12), 1873-1879.

Schaack, M. M., \& Marth, E. H. (1988). Survival of Listeria monocytogenes in refrigerated cultured milks and yogurt. Journal of Food Protection, 51(11), 848-852.

Schmidt, J. L., Tourneur, C., \& Lenoir, J. (1994). Fonction et choix des bactéries lactiques laitières. In H. Roissart \& F.M. II Luquet (Eds.), Bactéries lactiques (pp. 37-46). Paris: Lorica.

Shabbir, U., Huma, N., \& Javed, A. (2019). Compositional and textural properties of goat's milk cheese prepared using dahi (yogurt) as the starter culture. Brazilian Journal of Food Technology, 22, e2018289. http://dx.doi.org/10.1590/1981-6723.28918.

Silva, B. S., Resende, S. R., Souza, A. K., Silva, M. A. P., Plácido, G. R., \& Caliari, M. (2014). Sensory, physicochemical and microbiological characteristics of greek style yogurt flovored with pequi (Caryocar Brasiliense, Cambess). African Journal of Biotechnology, 13(37), 3797-3804. http://dx.doi.org/10.5897/AJB2014.14053.

Strahm W., Haldemann J., \& Stoffers H. (2014). Défauts des yogourts causes et mesures. Berne: Editeur Agroscope

Sudheer, K. S., Ahmed Syed, U., \& Ashok, P. (2006). Yogurt science and technology (2nd ed). Cambridge: Woodhead Publishing.

Sodini, I. \& Beal, C. (2012). Fabrication des yaourts et laits fermentés. Techniques de l'Ingénieur, BIO1, F6315.

Soustre, Y. (2007). Questions sur les qualités nutritionnelles des protéines laitières. Bio communication, 16, 01-04.

Oteng-Gyang, K. (1984). Introduction à la microbiologie alimentaire dans les pays chauds. Paris: Technique \& Documentation Lavoisier.

Tadjine, D., Boudalia, S., Bousbia, A., Khelifa, R., Mebirouk Boudechiche, L., Tadjine, A., \& Chemmam, M. (2020). Pasteurization effects on yield and physicochemical parameters of cheese in cow and goat milk. Food Science Technology, 40(3), 580-587. http://dx.doi. org/10.1590/fst.13119.

Tamime, A. Y., \& Robinson, R. K. (1999). Yogurt science and technology (2nd ed). Cambridge: Woodhead Publishing.

Vargas, M., Chafer, M., Albors, A., Chiralt, A., \& Gonzalez-Martınez, C. (2008). Physicochemical and sensory characteristics of yoghurt produced from mixtures of cows' and goats' milk. International Dairy Journal, 18(12), 1146-1152. http://dx.doi.org/10.1016/j. idairyj.2008.06.007.

Vignola, C. L. (2002). Science et technologie du lait: transformation du lait. Montréal: Presses Internationals Polytechnique. 567 p.

Wang, C., Chang, T., Yang, H., \& Cui, M. (2015). Antibacterial mechanism of lactic acid on physiological and morphological properties of Salmonella Enteritidis, Escherichia coli and Listeria monocytogenes. Food Control, 47, 231-236. 